\title{
Practical review of current approaches to diagnosis and treatment of transplant-associated thrombotic microangiopathy
}

\author{
Ivan S. Moiseev ${ }^{1}$, Tatyana G. Tsvetkova ${ }^{2}$, Tapani Ruutu ${ }^{3}$ \\ ${ }^{1}$ RM Gorbacheva Research Institute of Pediatric Oncology, Hematology and Transplantology, Pavlov University, St. Petersburg, \\ Russia \\ ${ }^{2}$ Nikiforov Russian Center of Emergency and Radiation Medicine, St. Petersburg, Russia \\ ${ }^{3}$ Clinical Research Institute, Helsinki University Hospital, Helsinki, Finland
}

Ivan S. Moiseev, PhD, MD, RM Gorbacheva Research Institute of Pediatric Oncology, Hematology and Transplantology, Pavlov University, 6-8 L Tolstoy St, 197022, St. Petersburg, Russia

Citation: Moiseev IS, Tsvetkova TG, Ruutu T. Practical review of current approaches to diagnosis and treatment of transplantassociated thrombotic microangiopathy. Cell Ther Transplant 2021; 10(2): 17-25.

\section{Summary}

Transplant-associated thrombotic microangiopathy (TA-TMA) is a rare complication of hematopoietic stem cell transplantation with an endothelial damage being the major cause of clinical signs. Currently, four major set of diagnostic criteria exist which capture different populations of patients with variable severity of endothelial dysfunction and target organ involvement. Absence of widely excepted criteria for TA-TMA severity, outcome and response measures complicate the comparison of different treatment approaches. Withdrawal or tapering of calcineurin inhibitors is a widely excepted intervention; however, there are studies that indicate no benefit of this intervention in improving overall survival. Different strategies of substituting calcineurin inhibitors with other immunosuppressive may also have impact on survival in TA-TMA patients.
Novel approaches in treatment include oligonucleotides and complement inhibitors. Indications for these treatments according to different diagnostic criteria are still to be defined. Currently published evidence highlight the need for cooperative effort to gather empirical data and harmonize definitions required for comparative clinical studies of novel agents.

\section{Keywords}

Thrombotic microangiopathy, hematopoietic stem cell transplantation, diagnostic criteria, calcineurin inhibitors, defibrotide, eculizumab.

\section{Introduction}

Transplant-associated thrombotic microangiopathy (TATMA) was initially identified as a complication of allogeneic hematopoietic stem cell transplantation (HSCT) in the late 1980-s, primary as a complication of a graft-versus-host disease (GVHD) prophylaxis with cyclosporine $[1,2]$. However, subsequently it was demonstrated that cyclosporine is not the only predisposing factor, and TA-TMA may be observed even after autologous HSCT [3] or high-dose chemotherapy [4]. Absence of diagnostic criteria for almost two decades precluded the appearance of any solid epidemiological data on the incidence of this complication. The reported incidence varied from $0.1 \%$ to $29 \%$. Mean incidence across studies was $8.2 \%$. Mortality in the majority of case series exceeded 50\% [5-9]. In the modern era, the incidence varies 
from $3 \%$ in the registry studies in predominantly adult population [10] to $16 \%$ in the pediatric prospective studies [11] This difference might represent identification and inclusion of mild TA-TMA cases in the prospective studies. In these recent studies TA-TMA was associated with additional 15\% mortality when compared to patients without TA-TMA, also reflecting the spectrum of TA-TMA severity $[9,11]$.

\section{Diagnostics of TA-TMA}

Part of the diagnosis is assessment of TA-TMA probability in the particular HSCT patient. The major risk factors are transplantation from alternative donors, HLA-mismatched donors, non-myeloablative conditioning or intensified myeloablative conditioning, use of anti-lymphocyte globulin, GVHD prophylaxis with combination of calcineurin and mTOR inhibitors and prior HSCT $[9,12,13]$. Genetic predisposition include polymorphism in the complement pathway genes, including CFH, CFHR, CFI, CFB, C3 and several others. Certain HLA alleles in recipients were also reported to predispose to TA-TMA. Usually presence of several genetic variants and a triggering factor is required for development of TA-TMA [14]. Although TA-TMA may be not associated with additional complications of HSCT common, major clinical triggers are acute GVHD, particularly steroid-refractory form, viral reactivations, high concentrations of calcineurin inhibitors, or severe bacterial infections [15-17].

It should be admitted that currently there are no uniform criteria for TA-TMA. Primary TA-TMA was identified by the presence of microangiopatic hemolysis, fragmented cells (schistocytes), elevation of lactate dehydrogenase (LDH), thrombocytopenia, and organ damage due to microangiopathy, including renal failure or neurologic dysfunction $[5,6]$.
In 2005-2007, two consensus diagnostic criteria were developed, including Blood and Marrow Transplant Clinical Trials Network (BMT CTN) by Ho et al. [19] and International Working Group (IWG) by Ruutu T. et al. [20]. Analysis of the overlap between these criteria by Cho et al. has shown that twice less patients are diagnosed with TA-TMA using IWG criteria, while less than $10 \%$ of patients diagnosed with IWG criteria do not fall into the frame of BMT CTN criteria [21]. The "overall TMA" criteria were proposed on the basis on this analysis, i.e., $\geq 2 \%$ of schistocytes, elevation of $\mathrm{LDH}$, decrease of hemoglobin and platelets. These "overall TMA" criteria are the most commonly used in the studies of novel agents (Table 1). Besides the differences with diagnostic criteria there is a technical problem with the key laboratory index of TA-TMA: schistocyte quantification, which is not standardized. Therefore, its morphological evaluation can provide various results from one laboratory to another [22].

There are several reasons for the non-uniformity of accepted criteria. First, TA-TMA is a syndrome with endothelial dysfunction as the key pathogenetic feature. However, some degree of endothelial injury is present in all HSCT recipients [23]. Of note, the median level of schistocytes after allogeneic HSCT is around $1 \%$, which is very close to the diagnostic level of BMT CTN criteria [24]. This difference could be easily alleviated by the differences in the morphological practices between transplantation centers. An autopsy study demonstrated $10 \%$ of patients who died from various causes had evidence of renal microangiopathy [25]. Other complications of HSCT that are also associated with significant endothelial injury can mimic TA-TMA. These are steroid-refractory GVHD, hemorrhagic viral enterocolitis, sepsis and hemorrhagic cystitis $[25,27,28]$. Thus, there is a spectrum of patients with various degrees of endothelial injury and

Table 1. Overview of different diagnostic TA-TMA criteria

\begin{tabular}{|l|l|l|l|}
\hline BMT CTN, Ho VT et al. [19] & IWG, Ruutu T et al. 20] & Overall TMA, Cho BS et al. [21] & Jodele S et al. [29] \\
\hline $\begin{array}{l}\text { Schistocytes } \geq 2 \text { per } \\
\text { high-power field on } \\
\text { peripheral smear }\end{array}$ & Schistocytes $\geq 4 \%$ & Schistocytes $\geq 2 \%$ & Schistocytes, any level \\
\hline $\begin{array}{l}\text { Elevated LDH } \\
\text { Renal* and/or neurologic } \\
\text { dysfunction }\end{array}$ & $\begin{array}{l}\text { Elevated LDH novo, prolonged or } \\
\text { progressive thrombocytopenia } \\
<50 \text { 10\%/L }\end{array}$ & Thrombocytopenia & Elevated LDH \\
\hline $\begin{array}{l}\text { Negative direct Coombs } \\
\text { test }\end{array}$ & $\begin{array}{l}\text { Decrease of hemoglobin or } \\
\text { transfusion requirement }\end{array}$ & $\begin{array}{l}\text { Decrease of hemoglobin or } \\
\text { transfusion requirement }\end{array}$ & $\begin{array}{l}\text { De novo thrombocytopenia } \\
<50 \text { 109/L or } \geq 50 \% \text { decrease } \\
\text { in the platelet count }\end{array}$ \\
\hline & Decreased serum haptoglobin & $\begin{array}{l}\text { Decrease of hemoglobin or } \\
\text { transfusion requirement }\end{array}$ \\
\hline $\begin{array}{l}\text { Coefficient of diagnosed } \\
\text { patients: } 22.5 \text { [21] }\end{array}$ & $\begin{array}{l}\text { Coefficient of diagnosed } \\
\text { patients: xl.0 [21] }\end{array}$ & $\begin{array}{l}\text { Coefficient of diagnosed } \\
\text { patients: } x 5.0 \text { [21] }\end{array}$ & $\begin{array}{l}\text { Elevated plasma concentra- } \\
\text { tion of sC5b-9 }>1 \text { ULN }\end{array}$ \\
\hline
\end{tabular}

${ }^{*}$ Doubling of serum creatinine from baseline (baseline = creatinine before hydration and conditioning) or $50 \%$ decrease in creatinine clearance from baseline. 
complement activation after HSCT. In the absence of proven effective interventions it is hard to draw the border, where we can say that this degree of endothelial injury is TA-TMA. Emergence of novel therapies will drive the development of novel diagnostic criteria and this set of criteria will define the group of patients that will benefit from certain therapies.

On the other hand, TA-TMA is not only a syndrome with variable severity, but also a syndrome emerging due to a variety of etiological factors. In children, a clear relationship may exist between mutations in the complement -related genes, alterations in the complement pathway and evidence of complement activation that correlates with the clinical presentation. In pediatric cohort, the level of serum soluble membrane attack complex (C5b-9) was elevated in around $70 \%$ of TA-TMA patients. These patients had a more fulminate disease course and higher risk of mortality [29]. There are ethnic differences in the incidence of complement-associated TA-TMA. Hence, the exact percentage of this clinical entity may vary across countries [11]. However, in the adult population there is only limited data on complement activation after unmanipulated haploidentical transplantation [30], and In the general population of adult patients several relatively different entities can be distinguished: GVHD-related, drug-induced (primarily, calcineurin and mTOR inhibitors), infection-related (cytomegalovirus and herpes type 6 are most frequently reported viruses), and those associated with other HSCT toxicities. The same entity as in children with overt multiorgan failure and complement activation comprises only a minor subgroup of adult patients [13]. Vice versa $30 \%$ of children without complement activation, likely, have similar pathogenetic mechanisms to the adult population.

The large proportion of pediatric patients with complement activation led to the development of a diagnostic algorithm by Jodele $S$ et al. [31]. It involves screening with serial measurement of $\mathrm{LDH}$, proteinuria and blood pressure. If any of these parameters become abnormal, ADAMTS13-related TTP should be excluded and laboratory workout for TA-TMA should be performed. To confirm the diagnosis of TA-TMA, histological evidence of the organ involvement is sufficient. Alternatively, increased LDH, schistocytes on blood smear, de novo thrombocytopenia, or platelet transfusion dependence, arterial hypertension, proteinuria $\geq 30 \mathrm{mg} / \mathrm{dL}$ and elevation of soluble C5b-9 should be documented.

In clinical practice, local standards of TA-TMA diagnosis vary significantly due to above mentioned difficulties $[9,22]$, and it is hard to recommend one or another strategy. Before using certain diagnostic approach one should decide what will be an application of this approach.

Identification of patients with endothelial injury in the prospective clinical studies is one thing, selecting patients who will benefit from clinical interventions represents another task. However, several practical suggestions can be made to avoid under- and overdiagnosis of this complication. Regular screening of $\mathrm{LDH}$ and creatinine levels, proteinuria and blood pressure will identify potential patients at risk for TA-TMA. Further laboratory evaluation is required for the patients who have de novo grade 3-4 anemia or thrombocytopenia, never became transfusion-independent, or those who had acute kidney injury or neurologic dysfunction on the top of positive screening results. Other groups of patients without these key features are unlikely to require any interventions, even if TA-TMA evidence could be obtained from laboratory testing. Schistocyte evaluation is required to confirm the diagnosis, and Coombs test is required to rule out immune hemolytic anemia. When applying morphological criteria of TA-TMA, several rules were formulated for schistocyte quantification that allow to capture TMA-specific changes in the blood smears (Table 2) [22]. The patients with $\geq 2 \%$ schistocytes can be clinically considered having TA-TMA. Rising schistocyte and LDH levels on serial measurement additionally support the diagnosis. Although ADAMTS13 activity is included in the Jodele $S$ et al. algorithm [31], but the incidence of this TMA mechanism in HSCT recipients is limited to single observations $[32,33]$. Elevation of sC5b9 $>300 \mathrm{ng} / \mathrm{mL}$ and angiopoietin- 2 to $>3 \mathrm{ng} / \mathrm{mL}$ can also provide evidence in favor of TMA diagnosis [33].

There is no well-established system for assessment of TATMA severity. Certain clinical features associated with higher mortality were reported, e.g., presence of neurological signs, acute kidney injury, $\mathrm{LDH} \geq 2$ upper limits of normal (ULN), a need for $\geq 2$ medications to control hypertension $[29,34]$. The BMT CTN consensus proposed common toxicity criteria of severity, where grade 1 corresponded to absence of clinical consequences; grade 2 is assessed at elevated creatinine levels of $\leq 3$ ULN; grade 3 corresponded to creatinine levels of $>3$ ULN not requiring dialysis, and grade 4 was characterized as renal failure requiring dialysis, and/ or encephalopathy. Nonetheless, this severity system was not validated to predict survival of patients with TA-TMA and is rarely used during application of novel therapies.

\section{Treatment of transplant-associated thrombotic microangiopathy}

Currently, there are no established treatments of TA-TMA. Historically, therapeutic plasma exchange (TPE) was used, by analogy of thrombotic thrombocytopenic purpura, with a common standard of care. Despite early reports on its efficacy [35], the latest consensus established that average response rate, mostly defined by the subsided laboratory criteria, was $37 \%$ for 121 TPE-treated patients. Average mortality across all the patients was $79 \%$, and the consensus stated that plasma exchange should not be considered a standard of care for TA-TMA [36]. The controversial results of TPE treatment may be related to very low frequency of ADAMTS-13-associated mechanism in TA-TMA [33].

Several other treatments were used outside clinical trials in TA-TMA. These included rituximab [37, 38, 39], defibrotide $[40,41,42]$, and eculizumab $[43,44,45,46]$. Clinical efficacy and mechanisms of rituximab in TA-TMA can be hardly assessed with only seven patients reported in the literature. On the other hand, 165 patients were treated with either defibrotide or eculizumab with a very comparable response rate of $73 \%$ and $58 \%$, respectively. Nonetheless, overall mortality remained high with both treatments and was $40 \%$ across the studies. Particularly favorable results were reported by Jodele et al. with eculizumab in the pediatric cohort where large 
1. The following abnormal erythrocytes should be included in the schistocyte count:

- Triangular or microcrescent cells;

- Helmet cells;

- Keratocytes;

- Microspherocytes should be included in the schistocyte count if only 2 or more other forms of schistocytes are present. Their size should be comparable to the size of the other schistocytes and be not more than $4 \mu \mathrm{m}$. They should not contain central pallor except of rare instances;

- Other fragments of erythrocytes with irregular shape should be included in the schistocyte count if two more types are present and their size is comparable to the size of the other schistocytes;

- Degmacytes should be included despite it is a typical abnormal erythrocytes in deficiency of glucose 6-phosphate dehydrogenase, but their morphology is often undistinguishable from the schistocytes; they can be included given a low probability of undiagnosed G6PD deficiency in HSCT recipient.

2. Keratocytes, helmet cells, triangular cells and other erythrocyte fragments of irregular shape should contain at least two angles $\leq 90$ degrees.

3. The following abnormal erythrocytes should NOT be included the schistocyte count:

- Ovalocytes

- Dacryocytes

- Spherocytes

- Acantocytes

- Stomatocytes

- Target cells

4. In TA-TMA, three or more types of schistocytes should be present.

5. For TA-TMA cases the presence of helmet cells along with triangular cells are strongly required, although they may not be the prevalent forms.

6. Quantification of schistocytes should be done only if the clinician suspects TA-TMA, because up to 3 types of schistocytes could be present in cases of other posttransplant complications.

7. The 100x magnification is recommended if there are difficulties with schistocyte identification.

8. For the uniform distribution of erythrocytes on the blood slide, the use of commercially available slide makers is recommended.

9. Before the schistocyte quantification, one should assess the number of erythrocytes in the power field, because significant differences may exist for TA-TMA patients, due to severe anemia.

10. In cases of tightly distributed erythrocytes, the cell shape may replicate the contours of adjacent cells and have helmet-like appearance. These erythrocytes should not be counted as schistocytes.

11. Certain clinical situations should be taken into account:

- In myelofibrosis, the false positive results are due to anisocytosis and poikilocytosis, and quantification of small ovalocytes and dacryocytes as schistocytes.

- In B12-deficiency hemolysis, 3 types of schistocytes are present. The difference with TA-TMA is a more uniform morphology of schistocytes. Appropriate differential diagnosis should include measurement of B12 level.

- In myelodysplastic syndrome, two types of schistocytes, i.e., keratocytes and microspherocytes could be defined.

The false positive results are due to poikilocytosis and quantification of small ovalocytes as schistocytes.

- In autoimmune hemolytic anemia, 3 types of schistocytes are present. The difference with TA-TMA is in more uniform morphology of schistocytes, and presence of central pallor in the majority of the abnormal erythrocytes. Morphological distinction could be difficult. The differential diagnosis requires the Coombs or other tests for autoimmune hemolysis.

- In hemoglobinopathies, the false positive results could be due to quantification of helmet-like and keratocyte-like cells. They could be discriminated from schistocytes by a comparable or larger cell size than the background erythrocytes and visible central pallor.

proportion of patients had mutations in complement-related genes and clear laboratory signs of complement activation $[11,12]$. In this cohort, evaluation of eculizumab concentrations demonstrated higher drug clearance than in paroxysmal nocturnal hemoglobinuria as one of the mechanisms behind the lack of efficacy. Thus, Jodele et al. proposed the algorithm of weekly induction doses and additional induction doses based on daily CH50 activity [47]. Two small clinical trials also evaluated narsoplimab, a mannan-binding lectin-associated serine protease- 2 inhibitor, also targeting complement pathway. Improvement of laboratory signs was observed in a proportion of patients and overall survival was $50 \%[48,49]$ (Table 3). Looking at the response and survival rate of all these pharmacological treatments, it is clear that, if compared to PTE, they have merit in a proportion of patients. However, their administration was based on various 
Table 3. Results of clinical studies in transplant-associated thrombotic microangiopathy

\begin{tabular}{|l|l|l|l|l|}
\hline Treatment & Total, N & Responders, N & Mortality, N & Reference \\
\hline Rituximab & 1 & 1 & 0 & {$[37]$} \\
\hline Rituximab & 1 & 1 & 0 & {$[38]$} \\
\hline Rituximab & 5 & 4 & 2 & {$[39]$} \\
\hline Defibrotide & 16 & 11 & 7 & {$[40]$} \\
\hline Defibrotide & 39 & 30 & 15 & {$[41]$} \\
\hline Defibrotide & 12 & 8 & 6 & {$[42]$} \\
\hline Eculizumab & 12 & 6 & 8 & {$[43]$} \\
\hline Eculizumab & 64 & 36 & 22 & {$[44]$} \\
\hline Eculizumab & 5 & 4 & 2 & {$[45]$} \\
\hline Eculizumab & 10 & 7 & 4 & {$[46]$} \\
\hline Narsoplimab & 19 & N/A & 9 & {$[48]$} \\
\hline Narsoplimab & 5 & 4 & 3 & {$[49]$} \\
\hline
\end{tabular}

indications and various diagnostic criteria. In the absence of severity criteria, it is also impossible to compare the groups of patients in these studies. Thus, it is difficult to recommend either approach as the first-line treatment. On the other hand, currently published data on the pharmacological treatments rather postulates the necessity for common criteria for severity and response based on empirical data.

Common first-line intervention for TA-TMA is to manipulate with immunosuppression regimens. The idea comes from early observations that inclusion of cyclosporine A in the prophylaxis regimens was associated with first documented TA-TMA cases $[1,2]$. Further evidence for toxicity of calcineurin inhibitors (CNIs) towards endothelium [50] created the basis for tapering or discontinuation of CNIs in patients with TA-TMA [51]. Due to essential needs for GVHD control in the majority of these patients, glucocorticosteroids were historically administered in the most patients after CNIs discontinuation. Recent Blood and Marrow Transplant Clinical Trials Network Toxicity Committee consensus supported discontinuation of CNIs as the primary intervention based on expert opinion [36]. Nonetheless, the large single-center analysis by $\mathrm{Li}$ et al. did not show any benefit in terms of overall survival, when tapering or discontinuing CNIs $v s$ their continuation in all subgroups of TMA patients, irrespective of type of GVHD prophylaxis [52]. It seems that, like all other interventions in TMA, sole discontinuation of CNIs does not lead to resolution of symptoms in all the patients, but the time to resolution might be quicker. Also, the different centers are testing other type of agents for GVHD prophylaxis instead of CNIs, with effects on survival outcomes. In our single-center analysis, substitution of CNIs by sirolimus in severe GVHD proved to be superior to steroids [53]. Novel agents, like JAK inhibitors, might also facilitate sufficient GVHD control instead of CNIs without additional endothelial damage [54]. Further investigation of different substitution strategies are warranted. Even in continuation strategies, a pause before obtaining CNI concentration is a rational approach, because the majority of patients show a transitory reduction of CNIs clearance, and high concentrations are common at TMA diagnosis.

\section{Conclusion}

Along with clinical criteria, diagnostics of TA-TMA involves several laboratory tests, of which erythrocyte shistocytosis remain a less standardized criterion $[22,55]$. Screening of LDH and creatinine levels, proteinuria and blood pressure, exclusion of autoimmune haemolysis should discern potential patients at risk for TA-TMA.

Further improvement of care in TA-TMA requires harmonization of definitions for mortality risk, response, outcome measures and indications for treatment. Since this is a relatively rare entity and even large centers rarely has information on more than 50-100 cases, cooperative effort to gather empirical data is crucial to formulate these definitions, only after that existing and novel therapies can be compared without bias in the multicenter studies. For current clinical practice, internal institutional guidelines should select one of the diagnostic criteria and adhere to them. Reduction or discontinuation of calcineurin inhibitors should be considered in all patients, but internal guidelines for substitution with active immunosuppressive agents should be developed for GVHD control. Novel treatments should be implemented in case of organ failure, or in patients not responding to immunosuppression manipulation.

\section{Conflicts of interest}

None reported.

\section{References}

1. Myers BD. Cyclosporine nephrotoxicity. Kidney Int. 1986;30(6):964-974. doi: 10.1038/ki.1986.280

2. Holler E, Kolb HJ, Hiller E, Mraz W, Lehmacher W, Gleixner B, Seeber C, Jehn U, Gerhartz HH, Brehm G, et al. Microangiopathy in patients on cyclosporine prophylaxis who developed acute graft-versus-host disease after HLA-identical bone marrow transplantation. Blood. 1989;73(7):20182024. PMID: 2496776 
3. Wassmann B, Martin H, Elsner S, Bruecher J, Thaiss F, Stahl RA, Hoelzer D. Microangiopathic hemolytic anemia and renal impairment following autologous bone marrow transplantation: a case of hemolytic uremic syndrome? Bone Marrow Transplant. 1994;14(5):849-851. PMID: 7889019

4. Fisher DC, Sherrill GB, Hussein A, Rubin P, Vredenburgh JJ, Elkordy M, Ross M, Petros W, Peters WP. Thrombotic microangiopathy as a complication of high-dose chemotherapy for breast cancer. Bone Marrow Transplant. 1996; 18(1):193198. PMID: 8832014

5. Iacopino P, Pucci G, Arcese W, Bosi A, Falda M, Locatelli F, Marenco P, Miniero R, Morabito F, Rossetti F, Sica S, Uderzo C, Bacigalupo A. Severe thrombotic microangiopathy: an infrequent complication of bone marrow transplantation. Gruppo Italiano Trapianto Midollo Osseo (GITMO). Bone Marrow Transplant. 1999; 24(1):47-51. doi: 10.1038/ sj.bmt. 1701830

6. Pettitt AR, Clark RE. Thrombotic microangiopathy following bone marrow transplantation. Bone Marrow Transplant. 1994;14:495-504.

7. Kanamori H, Maruta A, Sasaki S, Yamazaki E, Ueda S, Katoh K, Tamura T, Otsuka-Aoba M, Taguchi J, Harano H, Ogawa K, Mohri H, Okubo T, Matsuzaki M, Watanabe S, Koharazawa H, Fujita H, Kodama F. Diagnostic value of hemostatic parameters in bone marrow transplant-associated thrombotic microangiopathy. Bone Marrow Transplant. 1998;21(7):705-709. doi: 10.1038/sj.bmt.1701151

8. Platzbecker U, von Bonin M, Goekkurt E, Radke J, Binder M, Kiani A, Stoehlmacher J, Schetelig J, Thiede C, Ehninger G, Bornhäuser M. Graft-versus-host disease prophylaxis with everolimus and tacrolimus is associated with a high incidence of sinusoidal obstruction syndrome and microangiopathy: results of the EVTAC trial. Biol Blood Marrow Transplant. 2009;15(1):101-108. doi: 10.1016/j.bbmt.2008.11.004

9. George JN, Li X, McMinn JR, Terrell DR, Vesely SK, Selby GB. Thrombotic thrombocytopenic purpura-hemolytic uremic syndrome following allogeneic HPC transplantation: a diagnostic dilemma. Transfusion. 2004;44(2):294-304.

10. Epperla N, Li A, Logan B, Fretham C, Chhabra S, Aljurf M, Chee L, Copelan E, Freytes CO, Hematti P, et al. Incidence, risk factors for and outcomes of transplant-associated thrombotic microangiopathy. Br J Haematol. 2020; 189(6):1171-1181. doi: 10.1111/bjh.16457

11. Dandoy CE, Rotz S, Alonso PB, Klunk A, Desmond C, Huber J, Ingraham H, Higham C, Dvorak CC, Duncan C, et al. A pragmatic multi-institutional approach to understanding transplant-associated thrombotic microangiopathy after stem cell transplant. Blood Adv. 2021; 5(1):1-11. doi: 10.1182/bloodadvances.2020003455

12. Jodele S, Dandoy CE, Myers K, Wallace G, Lane A, Teusink-Cross A, Weiss B, Davies SM. High-dose Carboplatin/ Etoposide/Melphalan increases risk of thrombotic microangiopathy and organ injury after autologous stem cell transplantation in patients with neuroblastoma. Bone Marrow Transplant. 2018; 53(10):1311-1318. doi: 10.1038/s41409$\underline{018-0159-8}$
13. Li A, Wu Q, Davis C, Kirtane KS, Pham PD, Sorror ML, Lee SJ, Gopal AK, Dong JF, Garcia DA, Weiss NS, R Hingorani $S$. Transplant-associated thrombotic microangiopathy is a multifactorial disease unresponsive to immunosuppressant withdrawal. Biol Blood Marrow Transplant. 2019; 25(3):570576. doi: 10.1016/j.bbmt.2018.10.015

14. Jodele S, Zhang K, Zou F, Laskin B, Dandoy CE, Myers KC, Lane A, Meller J, Medvedovic M, Chen J, Davies SM. The genetic fingerprint of susceptibility for transplant-associated thrombotic microangiopathy. Blood. 2016; 127(8):989-996. doi: 10.1182/blood-2015-08-663435

15. Balassa K, Andrikovics H, Remenyi P, Batai A, Bors A, Kiss KP, Szilvasi A, Rajczy K, Inotai D, Gopcsa L, et al. The potential role of HLA-DRB $1^{\star} 11$ in the development and outcome of haematopoietic stem cell transplantation-associated thrombotic microangiopathy. Bone Marrow Transplant. 2015; 50(10):1321-1325. doi: 10.1038/bmt.2015.161

16. Takatsuka H, Wakae T, Mori A, Okada M, Fujimori Y, Takemoto Y, Okamoto T, Kanamaru A, Kakishita E. Endothelial damage caused by cytomegalovirus and human herpesvirus-6. Bone Marrow Transplant. 2003; 31(6):475479. doi: 10.1038/sj.bmt.1703879

17. Kraft S, Bollinger N, Bodenmann B, Heim D, Bucher C, Lengerke C, Kleber M, Tsakiris DA, Passweg J, Tzankov A, Medinger M. High mortality in hematopoietic stem cell transplant-associated thrombotic microangiopathy with and without concomitant acute graft-versus-host disease. Bone Marrow Transplant. 2019; 54(4):540-548. doi: 10.1038/ $\underline{\text { s41409-018-0293-3 }}$

18. Matsuda Y, Hara J, Miyoshi H, Osugi Y, Fujisaki H, Takai K, Ohta H, Tanaka-Taya K, Yamanishi K, Okada S. Thrombotic microangiopathy associated with reactivation of human herpesvirus- 6 following high-dose chemotherapy with autologous bone marrow transplantation in young children. Bone Marrow Transplant. 1999; 24(8):919-923. doi: 10.1038/ sj.bmt. 1702003

19. Ho VT, Cutler C, Carter S, Martin P, Adams R, Horowitz M, Ferrara J, Soiffer R, Giralt S. Blood and marrow transplant clinical trials network toxicity committee consensus summary: thrombotic microangiopathy after hematopoietic stem cell transplantation. Biol Blood Marrow Transplant. 2005; 11(8):571-575. doi: 10.1016/j.bbmt.2005.06.001

20. Ruutu T, Barosi G, Benjamin RJ, Clark RE, George JN, Gratwohl A, Holler E, Iacobelli M, Kentouche K, Lämmle B, et al.; European Group for Blood and Marrow Transplantation; European LeukemiaNet. Diagnostic criteria for hematopoietic stem cell transplant-associated microangiopathy: results of a consensus process by an International Working Group. Haematologica. 2007; 92(1):95-100. doi: 10.3324/haematol.10699

21. Cho BS, Yahng SA, Lee SE, Eom KS, Kim YJ, Kim HJ, Lee S, Min CK, Cho SG, Kim DW, et al. Validation of recently proposed consensus criteria for thrombotic microangiopathy after allogeneic hematopoietic stem-cell transplantation. Transplantation. 2010; 90(8):918-926. doi: 10.1097/ TP.0b013e3181f24e8d 
22. Moiseev IS, Tsvetkova T, Aljurf M, Alnounou RM, Bogardt J, Chalandon Y, Drokov MY, Dvirnyk V, Faraci M, Friis LS, et al. Clinical and morphological practices in the diagnosis of transplant-associated microangiopathy: a study on behalf of Transplant Complications Working Party of the EBMT. Bone Marrow Transplant. 2019; 54(7):1022-1028. doi: $10.1038 / \mathrm{s} 41409-018-0374-3$

23. Carreras E, Diaz-Ricart M. The role of the endothelium in the short-term complications of hematopoietic SCT. Bone Marrow Transplant. 2011; 46(12):1495-1502. doi: 10.1038/ $\underline{\text { bmt.2011.65 }}$

24. Lesesve JF, Alla F, Dugué F, Salignac S, Clément L, Lecompte T, Bordigoni P. Evaluation of schistocyte monitoring after haematopoietic stem cell transplantation. Int J Lab Hematol. 2011; 33(4):343-356. doi: 10.1111/j.1751553X.2010.01292.x

25. Girsberger M, Halter JP, Hopfer H, Dickenmann M, Menter T. Kidney pathology after hematologic cell transplantation-a single-center observation study of indication biopsies and autopsies. Biol Blood Marrow Transplant. 2018;24(3):571-580. doi: 10.1016/j.bbmt.2017.11.008

26. Luft T, Dietrich S, Falk C, Conzelmann M, Hess M, Benner A, Neumann F, Isermann B, Hegenbart U, Ho AD, Dreger P. Steroid-refractory GVHD: T-cell attack within a vulnerable endothelial system. Blood. 2011; 118(6):1685-1692. doi: 10.1182/blood-2011-02-334821

27. Symeonidis N, Jakubowski A, Pierre-Louis S, Jaffe D, Pamer E, Sepkowitz K, O'Reilly RJ, Papanicolaou GA. Invasive adenoviral infections in T-cell-depleted allogeneic hematopoietic stem cell transplantation: high mortality in the era of cidofovir. Transpl Infect Dis. 2007; 9(2):108-13. doi: 10.1111/j.1399-3062.2006.00184.x

28. Kaphan E, Germi R, Bailly S, Bulabois CE, Carré M, Cahn JY, Thiebaut-Bertrand A. Risk factors of BK viral hemorrhagic cystitis in allogenic hematopoietic stem cell transplantation. Transpl Infect Dis. 2021: e13601. doi: 10.1111/ tid.13601

29. Jodele S, Davies SM, Lane A, Khoury J, Dandoy C, Goebel J, Myers K, Grimley M, Bleesing J, El-Bietar J, et al. Diagnostic and risk criteria for HSCT-associated thrombotic microangiopathy: a study in children and young adults. Blood. 2014; 124(4):645-653. doi: 10.1182/blood-2014-03-564997

30. Qi J, Wang J, Chen J, Su J, Tang Y, Wu X, Ma X, Chen F, Ruan C, Zheng XL, et al. Plasma levels of complement activation fragments $\mathrm{C} 3 \mathrm{~b}$ and sC5b-9 significantly increased in patients with thrombotic microangiopathy after allogeneic stem cell transplantation. Ann Hematol. 2017; 96(11):18491855. doi: 10.1007/s00277-017-3092-9

31. Jodele S, Laskin BL, Dandoy CE, Myers KC, El-Bietar J, Davies SM, Goebel J, Dixon BP. A new paradigm: Diagnosis and management of HSCT-associated thrombotic microangiopathy as multi-system endothelial injury. Blood Rev. 2015; 29(3):191-204. doi: 10.1016/j.blre.2014.11.001

32. Peyvandi F, Siboni SM, Lambertenghi Deliliers D, Lavoretano S, De Fazio N, Moroni B, Lambertenghi Deliliers G, Mannuccio Mannucci P. Prospective study on the behaviour of the metalloprotease ADAMTS13 and of von Willebrand factor after bone marrow transplantation. Br J Haematol. 2006; 134(2):187-195. doi: 10.1111/j.1365-2141.2006.06126.x

33. Li A, Bhatraju PK, Chen J, Chung DW, Hilton T, Houck K, Pao E, Weiss NS, Lee SJ, Davis C, et al. Prognostic biomarkers for thrombotic microangiopathy after acute graft-versushost disease: a nested case-control study. Transplant Cell Ther. 2021; 27(4):308.e1-308.e8. doi: 10.1016/j.jtct.2020.12.010

34. Schoettler M, Lehmann LE, Margossian S, Lee M, Kean LS, Kao PC, Ma C, Duncan CN. Risk factors for transplant-associated thrombotic microangiopathy and mortality in a pediatric cohort. Blood Adv. 2020; 4(11):2536-2547. doi: 10.1182/bloodadvances.2019001242

35. Roy V, Rizvi MA, Vesely SK, George JN. Thrombotic thrombocytopenic purpura-like syndromes following bone marrow transplantation: an analysis of associated conditions and clinical outcomes. Bone Marrow Transplant. 2001; 27(6):641-646. doi: 10.1038/sj.bmt.1702849

36. Ho VT, Cutler C, Carter S, Martin P, Adams R, Horowitz M, Ferrara J, Soiffer R, Giralt S. Blood and marrow transplant clinical trials network toxicity committee consensus summary: thrombotic microangiopathy after hematopoietic stem cell transplantation. Biol Blood Marrow Transplant. 2005; 11(8):571-575. doi: 10.1016/j.bbmt.2005.06.001

37. Marr H, Mcdonald E, Merriman E, Smith M, Mangos $\mathrm{H}$, Stoddart C, et al. Successful treatment of transplant-associated microangiopathy with rituximab. N Z Med J. 2009; 122:72-75.

38. Jodele S, Bleesing JJ, Mehta PA, Filipovich AH, Laskin BL, Goebel J, Pinkard SL, Davies SM. Successful early intervention for hyperacute transplant-associated thrombotic microangiopathy following pediatric hematopoietic stem cell transplantation. Pediatr Transplant. 2012; 16(2):E39-42. doi: 10.1111/j.1399-3046.2010.01408.x

39. Au WY, Ma ES, Lee TL, Ha SY, Fung AT, Lie AK, Kwong YL. Successful treatment of thrombotic microangiopathy after haematopoietic stem cell transplantation with rituximab. Br J Haematol. 2007; 137(5):475-478. doi: 10.1111/j.13652141.2007.06588.x

40. Martínez-Muñoz ME, Forés R, Lario A, Bautista G, Bueno JL, de Miguel C, Navarro B, De Laiglesia A, Sánchez-Guerrero A, Cabrera JR, Duarte RF. Use of defibrotide to treat adult patients with transplant-associated thrombotic microangiopathy. Bone Marrow Transplant. 2019; 54(1):142-145. doi: 10.1038/s41409-018-0256-8

41. Yeates L, Slatter MA, Bonanomi S, Lim FLWI, Ong SY, Dalissier A, Barberi W, Shulz A, Duval M, Heilmann C, et al. Use of defibrotide to treat transplant-associated thrombotic microangiopathy: a retrospective study of the Paediatric Diseases and Inborn Errors Working Parties of the European Society of Blood and Marrow Transplantation. Bone Marrow Transplant. 2017; 52(5):762-764. doi: 10.1038/bmt.2016.351

42. Corti P, Uderzo C, Tagliabue A, Della Volpe A, Annaloro C, Tagliaferri E, Balduzzi A. Defibrotide as a promising treatment for thrombotic thrombocytopenic purpura in patients undergoing bone marrow transplantation. Bone Marrow Transplant. 2002; 29(6):542-543. doi: 10.1038/sj.bmt.1703414 
43. de Fontbrune FS, Galambrun C, Sirvent A, Huynh A, Faguer S, Nguyen S, Bay JO, Neven B, Moussi J, Simon L, et al. Use of eculizumab in patients with allogeneic stem cell transplant-associated thrombotic microangiopathy: a study from the SFGM-TC. Transplantation. 2015; 99(9):19531959. doi: $10.1097 /$ TP. 0000000000000601

44. Jodele S, Dandoy CE, Lane A, Laskin BL, Teusink-Cross A, Myers KC, Wallace G, Nelson A, Bleesing J, Chima RS, et al. Complement blockade for TA-TMA: lessons learned from a large pediatric cohort treated with eculizumab. Blood. 2020;135(13):1049-1057. doi: 10.1182/blood.2019004218

45. Vasu S, Wu H, Satoskar A, Puto M, Roddy J, Blum W, Klisovic R, Andritsos L, Hofmeister C, Benson DM, et al. Eculizumab therapy in adults with allogeneic hematopoietic cell transplant-associated thrombotic microangiopathy. Bone Marrow Transplant. 2016; 51(9):1241-1244. doi: $10.1038 / \mathrm{bmt} .2016 .87$

46. Rudoni J, Jan A, Hosing C, Aung F, Yeh J. Eculizumab for transplant-associated thrombotic microangiopathy in adult allogeneic stem cell transplant recipients. Eur J Haematol. 2018; 101(3):389-398. doi: 10.1111/ejh.13127

47. Jodele S, Fukuda T, Mizuno K, Vinks AA, Laskin BL, Goebel J, Dixon BP, Chima RS, Hirsch R, Teusink A, et al. Variable Eculizumab clearance requires pharmacodynamic monitoring to optimize therapy for thrombotic microangiopathy after hematopoietic stem cell transplantation. Biol Blood Marrow Transplant. 2016; 22(2):307-315. doi: 10.1016/j.bbmt.2015.10.002

48. Rambaldi A, Khaled S, Smith M, Zecca M, Kwong YL, Claes K, et al. Improved survival following OMS721 treatment of hematopoietic stem cell transplant-associated thrombotic microangiopathy. In: The $23^{\text {rd }}$ Congress of EHA. Stockholm, Sweden: European Hematology Association; 2018.

49. Khaled SK, Kwong YL, Smith M et al. Early results of Phase II Study using OMS721 in patients with hematopoietic stem cell transplant-associated thrombotic microangiopathy (HCT-TMA). Biol Blood Marrow Transplant 23 (2017) S18-S391.

50. Carreras E, Diaz-Ricart M. The role of the endothelium in the short-term complications of hematopoietic SCT. Bone Marrow Transplant. 2011; 46(12):1495-1502. doi: 10.1038/ bmt.2011.65

51. Worel N, Greinix HT, Leitner G, Mitterbauer M, Rabitsch W, Rosenmayr A, Höcker P, Kalhs P. ABO-incompatible allogeneic hematopoietic stem cell transplantation following reduced-intensity conditioning: close association with transplant-associated microangiopathy. Transfus Apher Sci. 2007; 36(3):297-304. doi: 10.1016/j.transci.2007.03.004

52. Li A, Wu Q, Davis C, Kirtane KS, Pham PD, Sorror ML, Lee SJ, Gopal AK, Dong JF, Garcia DA, et al. Transplant-associated thrombotic microangiopathy is a multifactorial disease unresponsive to immunosuppressant withdrawal. Biol Blood Marrow Transplant. 2019; 25(3):570-576. doi: 10.1016/j.bbmt.2018.10.015

53. Kanunnikov MM, Rakhmanova ZZ, Levkovsky NV, Vafina AI, Goloshapov OV, Shchegoleva TS, Vlasova JJ,
Paina OV, Morozova EV, Zubarovskaya LS, Kulagin AD, Moiseev IS. Conversion from calcineurin inhibitors to sirolimus in transplant-associated thrombotic microangiopathy. Clin Transplant. 2021; 35(2):e14180. doi: 10.1111/ctr.14180

54. Zeiser R, von Bubnoff N, Butler J, Mohty M, Niederwieser D, Or R, Szer J, Wagner EM, Zuckerman T, Mahuzier B, Xu J, Wilke C, Gandhi KK, Socié G; REACH2 Trial Group. Ruxolitinib for glucocorticoid-refractory acute graft-versus-host disease. N Engl J Med. 2020; 382(19):18001810. doi: 10.1056/NEJMoa1917635. Epub 2020 Apr 22. PMID: 32320566.

55. Zini G. Laboratory diagnostics of HSCT complications: immature platelets and RBCs. Cell Ther Transplant. 2021; 10(1): 6-12. doi: 10.18620/ctt-1866-8836-2021-10-1-6-12 


\title{
0бзор современных практических подходов к диагностике и лечению посттрансплантационной тромботической микроангиопатии
}

\author{
Иван С. Моисеев ${ }^{1}$, Татьяна Г. Цветкова ${ }^{2}$, Тапани Рууту ${ }^{3}$ \\ ${ }^{1}$ НИИ детской онкологии, гематологии и трансплантологии им. Р. М. Горбачевой, Первый Санкт-Петербургский \\ государственный медицинский университет им. акад. И.П. Павлова, Санкт-Петербург, Россия \\ ${ }^{2}$ Всероссийский центр экстренной и радиационной медицины имени А. М. Никифорова, Санкт-Петербург, Россия \\ ${ }^{3}$ Клинический Исследовательский Институт, Клиника Университета Хельсинки, Хельсинки, Финляндия
}

\section{Резюме}

Посттрансплантационная тромботическая микроангиопатия (ПТ-ТМА) является редким осложнением трансплантации гемопоэтических стволовых клеток с повреждением эндотелия, которое лежит в основе клинических симптомов этого осложнения. В настоящее время существует четыре основных консенсуса в отношении диагностических критериев, которые охватывают различные популяции пациентов с различной степенью эндотелиального повреждения и поражения органов-мишеней. Отсутствие общепризнанных критериев тяжести, ответа и конечных целей терапии ПТ-ТМА затрудняет сравнение разных методов лечения. Отмена или снижение дозы ингибиторов кальциневрина - широко распространенная интервенция при ПТ-ТМА, однако опубликованы также и данные исследований, которые указывают на отсутствие улучшения общей выживаемости от манипуляций с иммуносупрессивной терапией. По-видимому, различные стратегии замены ингибиторов кальциневрина другими иммуносупрессивными препаратами могут влиять на выживаемость у пациентов с ТА-ТМА.
Новые подходы к лечению включают олигонуклеотиды и ингибиторы комплемента, но показания для этих видов терапии в соответствии с различными диагностическими критериями еще предстоит определить в результате клинических исследований. Опубликованные в настоящее время данные подчеркивают необходимость совместных усилий для анализа эмпирических данных и утверждения клинических параметров, необходимых для сравнительных клинических исследований новых препаратов.

\section{Ключевые слова}

Тромботическая микроангиопатия, трансплантация гемопоэтических стволовых клеток, диагностические критерии, ингибиторы кальциневрина, дефибротид, экулизумаб. 